\title{
Differences in protodermal cell wall structure in zygotic and somatic embryos of Daucus carota (L.) cultured on solid and in liquid media
}

\author{
Izabela Dobrowolska • Oliwia Majchrzak • \\ Timothy C. Baldwin • Ewa U. Kurczynska
}

Received: 14 December 2010 / Accepted: 28 February 2011 /Published online: 20 March 2011

(C) The Author(s) 2011. This article is published with open access at Springerlink.com

\begin{abstract}
The ultrastructure, cuticle, and distribution of pectic epitopes in outer periclinal walls of protodermal cells of Daucus carota zygotic and somatic embryos from solid and suspension culture were investigated. Lipid substances were present as a continuous layer in zygotic and somatic embryos cultured on solid medium. Somatic embryos from suspension cultures were devoid of cuticle. The ultrastructure of the outer walls of protodermis of embryos was similar in zygotic and somatic embryos from solid culture. Fibrillar material was observed on the surface of somatic embryos. In zygotic embryos, in cotyledons and root pectic epitopes recognised by the antibody JIM5 were observed in all cell walls. In hypocotyls of these embryos, these pectic epitopes were not present in the outer periclinal and anticlinal walls of the protodermis. In somatic embryos from solid media, distribution of pectic epitopes recognised by JIM5 was similar to that described for their zygotic counterparts. In somatic embryos from suspension culture, pectic epitopes recognised by JIM5 were detected in all cell walls. In the cotyledons and hypocotyls, a punctate signal was observed on the outside of the protodermis. Pectic epitopes recognised by JIM7 were present in all cell walls independent of embryo organs. In zygotic embryos, this signal was punctate; in somatic embryos from both cultures,
\end{abstract}

Handling Editor: Liwen Jiang

I. Dobrowolska $(\bowtie) \cdot$ O. Majchrzak $\cdot$ E. U. Kurczynska Laboratory of Cell Biology, Faculty of Biology and Environment Protection, Silesian University,

Katowice, Poland

e-mail: izadobrowolska@interia.pl

T. C. Baldwin

School of Applied Sciences, University of Wolverhampton, Wulfruna Street,

Wolverhampton WV1 1SB, UK this signal was uniformly distributed. In embryos from suspension cultures, a punctate signal was detected outside the surface of cotyledon and hypocotyl. These data are discussed in light of current models for embryogenesis and the influence of culture conditions on cell wall structure.

Keywords Daucus carota . Cell wall ultrastructure . Cuticle $\cdot$ Pectic epitopes $\cdot$ Somatic embryos $\cdot$ Zygotic embryos

\section{Introduction}

Daucus carota is a plant species widely used for the in vitro propagation of plant material (Timbert et al. 1996; Shimazu and Kurata 1996; Mizukami et al. 2008). The most commonly used method for micropropagation of plants is a somatic embryogenesis which was originally described for carrot (Steward et al. 1958). This system is used not only from a practical point of view, it is also a good system for the investigation of mechanisms operating during embryogenesis (Pennell et al. 1992), especially in carrot where apart from the lack of the suspensor, somatic embryos in different stages of development are similar to their zygotic counterparts (Halperin 1964; Steeves and Sussex 1989). Over the past two decades, a great deal has been learnt regarding the biochemical, physiological, structural and genetic control of carrot embryogenesis (Kreuger and Hoist 1993; Wurtele et al. 1993; Toonen et al. 1997; Satoh 1998). However, to our knowledge little is known of the ultrastructure of the outer wall and cuticle of protodermal cells of zygotic and somatic embryos produced via different culture systems in $D$. carota.

The outer cell wall and cuticle of protodermal/epidermal cells are important regions of plant as they lie at the border 
between the organism and the environment, thereby mediating information exchange between these two. The cuticle limits water loss, gas exchange, provides a mechanical barrier and participates in exchange factors between the plant and its surroundings (Kerstiens 1996; Kerstiens 2006; Kosma et al. 2009; Koch and Barthlott 2009).

Analysis of the outer wall of protodermal cells of zygotic embryos from different plants including Arabodopsis (Bowman and Mansfield 1993; Rodkiewicz et al. 1994) and maize (van Lammeren 1986) has shown that the cuticle is present at their surface. However, it exists in different degrees, structure and composition (Newcomb 1973; Chamberlin et al. 1993; Szczuka 1995; Yeung et al. 1996; Szczuka and Szczuka 2003). Our knowledge regarding the structure and composition of the outer cell wall of protodermal cells covering the somatic embryos is scarce. For example, in the case of chicory embryos from liquid culture, the outer protodermal walls was described on the ultrastructural level, but without information about the presence of cutin on the surface (Chapman et al. 2000).

Changes in outer cell wall composition have previously been largely described in relation to responses to the environment (Bobák et al. 2003). Pectins are shown to have an important structural role in the control of cell wall porosity (Baron-Epel et al. 1988; Brummell 2006), cell-cell adhesion (Carpita and Gibeaut 1993; Atkinson et al. 2002; Bouton et al. 2002) and to participate in various developmental processes such as cell elongation (Hetherington and Fry 1993; McCann et al. 1993; Derbyshire et al. 2007) and cell differentiation ( $\mathrm{Li}$ et al. 1994; Riederer and Schreiber 2001; Motose et al. 2004). Several such studies have indicated a role for pectic polysaccharides in embryogenesis and organogenesis. Differences in methyl esterification of homogalacturonans were found to accompany the acquisition of competence for somatic embryogenesis in Cichory (Chapman et al. 2000), Cocos (Verdeil et al. 2001) or Triticum (Konieczny et al. 2007). During development of carrot embryos in suspension culture, changes in the sugar composition of pectic chains were reported (Kikuchi et al. 1995). Moreover, pectin oligosaccharide fragments also function as signalling molecules involved in the regulation of developmental processes (Dumville and Fry 2000; Wisniewska and Majewska-Sawka 2007; Bárány et al. 2010; Louvet et al. 2011).

The objective of the current study was to investigate the hypothesis that the 'conditions' in which somatic embryos develop influence the structure of the outer periclinal walls of protodermal cells. To test this hypothesis, the ultrastructure, cuticle and distribution of some pectin epitopes in outer walls of protodermal cells from mature somatic embryos growing in different conditions (air-like solid culture and liquid suspension culture) were investigated.
The same features of the outer walls of protodermis were analysed in mature zygotic embryos.

\section{Materials and methods}

Plant material and culture conditions

The current study was performed on mature somatic and zygotic embryos of carrot (D. carota L., cultivar Trophy). Zygotic embryos were mature in physiological sense (harvested from dry seeds). Somatic embryos were recognised as mature according to morphological features described by Raghavan (1986). For each analysis, at least ten embryos were used. Figures shown in this paper are representative examples.

\section{Suspension culture}

Seeds were surface sterilized by soaking in $75 \%$ ethanol for $10 \mathrm{~min}$ and followed by $1 \%$ sodium hypochlorite for $25 \mathrm{~min}$. They were then washed extensively in sterile distilled water, placed on B5 medium (Gamborg et al. 1968; Sigma-Aldrich) supplemented with sucrose $(20 \mathrm{~g} / \mathrm{l}$; POCH, Poland) and solidified with agar (7 g/l; Sigma-Aldrich) and grown for $1-2$ weeks at $23 \pm 1{ }^{\circ} \mathrm{C}$ in darkness. Hypocotyl segments $(1-2 \mathrm{~cm}$ long) from seedlings were placed on callus induction solid medium and cultured for 1 month at $22 \pm 1{ }^{\circ} \mathrm{C}$ under a $16 / 8$-h (light/dark) photoperiod with artificial illumination (light intensity $20 \mu \mathrm{M} / \mathrm{m} / \mathrm{s}$ ). The induction solid medium (E5) contained B5 medium supplemented with $5 \mu \mathrm{M}$ 2,4-D (2,4-dichlorophenoxyacetic acid; Sigma-Aldrich) and $20 \mathrm{~g} / \mathrm{l}$ sucrose, solidified with agar $(7 \mathrm{~g} / \mathrm{l})$. After 1 month, explants had become overgrown with callus and they were transferred to MSD liquid medium containing vitamins and microelements according to Murashige and Skoog (1962; SigmaAldrich), and $1 \mathrm{mg} / \mathrm{l}$ of 2,4-D and sucrose $(20 \mathrm{~g} / \mathrm{l})$. In order to induce embryogenesis, after 4 weeks, a fraction of embryogenic cell clusters was transferred to liquid MS medium without 2,4-D (MSO medium). Suspension cultures were incubated on a rotary shaker at $120 \mathrm{rpm}, 24 \pm 1^{\circ}$ C, $16 \mathrm{~L} / 8 \mathrm{D}$, at light intensity $20 \mu \mathrm{M} / \mathrm{m} / \mathrm{s}$. Mature embryos were collected after $2-3$ weeks.

\section{Solid medium culture}

In order to establish the embryogenic cultures on solid medium, the suspension embryogenic culture, prepared as described above, was used. Two-week-old suspension culture was sieved through nylon mesh (pore size $60 \mu \mathrm{m}$ ) to separate a fraction enriched for embryogenic cells, embryogenic clusters and proembryogenic masses from 
the embryo rich fraction. The fraction of size below $60 \mu \mathrm{m}$ (embryogenic cells, embryogenic clusters and proembryogenic masses) was transferred to the 2,4-D free MS solid medium, solidified with agar $(7 \mathrm{~g} / \mathrm{l})$ and subcultured for 1-2 weeks.

\section{Zygotic embryos}

Zygotic embryos of carrot were obtained from dry seeds according to the method established earlier by van Engelen et al. (1991). Seeds were imbibed in water for $2 \mathrm{~h}$. Next, the embryos were gently excised from the seed.

Sample processing and analysis

\section{Lipid substances}

For histochemical staining, embryos were fixed overnight at $4 \pm^{\circ} \mathrm{C}$ with $3 \%$ glutaraldehyde (Sigma-Aldrich) in $1 / 15 \mathrm{M}$ phosphate buffer at $\mathrm{pH}$ 7.0, dehydrated in ethanol series and embedded in Steedman's wax (Baluška et al. 1992; Sigma-Aldrich). Longitudinal sections $(6 \mu \mathrm{m}$ thick) were cut with the Zeiss rotary microtome (HYRAX M40, Zeiss,) collected on microscope slides coated with Haupt's adhesive, dewaxed with absolute ethanol, and stained with Nile red (Sigma-Aldrich) to detect lipid substances on the embryo surface (Lee et al. 2006). A stock solution of Nile red $(500 \mu \mathrm{g} / \mathrm{ml})$ was prepared in acetone, stored chilled and protected from light (Fowler and Greenspan 1985). A fresh staining solution of Nile red was made by addition of stock solution to PBS buffer to make a 2:100 dilution. Samples were incubated with dye for $10 \mathrm{~min}$. Excess of dye was removed by brief rinsing in PBS. Sections were examined using epifluorescence microscope (Olympus BX41) in a blue light (excitation filter 470-490, barrier filter $520 \mathrm{~nm}$, gold-red fluorescence).

\section{Transmission Electron Microscopy}

In order to examine material by transmission electron microscopy (TEM), embryos were fixed overnight at $4 \pm$ $1{ }^{\circ} \mathrm{C}$ with $2 \%$ EM quality glutaraldehyde and $1 \%$ formaldehyde in $1 / 15 \mathrm{M}$ phosphate buffer, at $\mathrm{pH} 7$, postfixed with $1 \%$ osmium tetroxide in phosphate buffer, at $\mathrm{pH} 7$ (for $1 \mathrm{~h}$ ), dehydrated with an ethanol series and embedded in epon resin 812 (Sigma-Aldrich) according to a procedure described earlier (Hawes and Satiat-Jeunemaitre 2001). Moreover, just before the last step of dehydration samples were treated with ruthenium red (in absolute ethanol; Sigma-Aldrich) to stain for pectins (Wi et al. 2005). Ultrathin longitudinal sections ( $90 \mathrm{~nm}$ thick) were cut with a Leica ultramicrotome (EM UC6, Leica Microsystems, Germany), mounted on copper grids (200 mesh). Subse- quently, sections were stained with $13 \%$ uranyl acetate (dissolved in 50\% ethanol; Sigma-Aldrich) for $10 \mathrm{~min}$ in total darkness at room temperature, dehydrated in five changes of $50 \%$ ethanol, followed by lead citrate (SigmaAldrich) prepared according to Reynolds' method (Reynolds 1963) for $7 \mathrm{~min}$ at room temperature and eventually, samples were washed in five changes of sterile physiological salt solution. The sections were examined and photographed on Hitachi H500 transmission electron microscope operated at $75 \mathrm{kV}$ (Hitachi High Technologies America, Inc.). The ultrastructure of outer periclinal wall of protodermal cells on the each embryo organ (cotyledons, hypocotyl, root) was analysed.

\section{Immunofluorescence microscopy}

For immunofluorescence microscopy, embryos were fixed overnight at $4 \pm 1{ }^{\circ} \mathrm{C}$ with $1 \%$ glutaraldehyde (SigmaAldrich) and 4\% paraformaldehyde (Fluka) in PBS buffer, pH 7.2, supplemented with sucrose (1\%), Triton X-100 (0.1\%; Sigma-Aldrich) and $\mathrm{CaCl}_{2}(2 \mathrm{mM}$; $\mathrm{POCH}$, Poland; Chen and Baldwin 2007). Fixative was freshly prepared prior to fixation and kept on ice. Fixed samples were dehydrated with an ethanol series and infiltrated in a series of absolute ethanol and L.R. White resin (Sigma-Aldrich) at room temperature. Subsequently, samples were embedded in pure L.R. White resin and polymerized at $50^{\circ} \mathrm{C}$ for $8 \mathrm{~h}$. A series of longitudinal sections ( $1 \mu \mathrm{m}$ thick) were cut on the ultramicrotome (EM UC6, Leica Microsystems, Germany) and collected onto poly-L-lysine coated microscope slides (Menzel Gläser, Germany). For immunofluorescence labelling, sections were prepared according to Chen and Baldwin (2007). Briefly, sections were incubated in $1 \%$ $\mathrm{NaB}_{4}$ (in PBS, $\mathrm{pH}=7.2$ ) and treated with blocking buffer (2\% BSA, FCS in PBS-HCl, pH 7.2). Subsequently, sections were incubated with primary antibodies JIM5 or JIM7 for pectic epitopes overnight at $4^{\circ} \mathrm{C}$ to locate low methyl-esterified and highly methyl-esterified pectic polisaccharides, respectively (Knox et al. 1990). Cy2conjugated AffiniPure goat anti-rat $\operatorname{IgG}(\mathrm{H}+\mathrm{L})$ antisera (Jackson ImmunoResearch Laboratories, USA) was used as the secondary antibody for detection of the both of epitopes. Labelling specificity was determined on the basis of following negative control: incubation of samples with blocking buffer instead of primary antibodies. Samples were viewed on an Olympus BX41 epifluorescence microscope under illumination with blue light (excitation filter $470-490 \mathrm{~nm}$, barrier filter $520 \mathrm{~nm}$, green fluorescence). Images were captured using an Olympus XC50 color camera accompanied with Olympus analySIS software. Localization of pectin epitopes in outer periclinal cell walls of embryos protodermis was examined. 


\section{Measurements}

In order to determine the thickness of the cuticle, six embryos from each type were measured, and for each embryo organ, a minimum of 20 measurements were performed. Cuticle thickness was assessed statistically (Student $t$ test, $p<0.05$ ).

\section{Results}

Distribution of lipid substances - cuticle at the protodermal cells surface

In zygotic embryos of $D$. carota at the mature stage of development, Nile red staining indicated that cuticular substances were present on the surface of all protodermal cells independent of the embryo organ (cotyledon-Fig. 1a, hypocotyl-Fig. 1b, root-Fig. 1c).

Positive Nile red staining of the outer layer of protodermal cell walls in somatic embryos growing on solid medium indicated that cuticular substances were present at the embryo surface. The cuticular layer covered all protodermal cells, including cotyledons (Fig. 1d), hypocotyls (Fig. 1e), the shoot and root pole (Fig. 1f).
Detailed analysis of this layer in zygotic and somatic embryos from solid medium did not reveal any differences in the presence of cutin between these embryos apart from the thickness of the cuticle. In the case of zygotic embryos, the cuticular layer was thinner (on average: cotyledons$0.07 \mu \mathrm{m}$, hypocotyls $-0.06 \mu \mathrm{m}$, root $-0.08 \mu \mathrm{m})$ in comparison to somatic embryos from solid medium (on average: cotyledons $-0.13 \mu \mathrm{m}$, hypocotyls $-0.16 \mu \mathrm{m}$, root $-0.13 \mu \mathrm{m})$ and the difference of cuticle thickness between organs was statistically significant $(p<0.05)$.

Analysis of the presence of lipid substances, localized with the use of Nile red staining at the surface of somatic embryos growing in suspension culture, revealed that in most (10 from 12) embryos there was no cuticular layer at their surface (cotyledon-Fig. 1g, hypocotyl-Fig. 1h, root-Fig. 1i). If lipid substances were present at the embryo surface, the cuticle was not continuous around the entire embryo.

Cell wall and cuticle ultrastructure

\section{Zygotic embryos}

Ultrastructural analysis of zygotic embryos was limited to the outer periclinal walls of protodermal cells. In zygotic
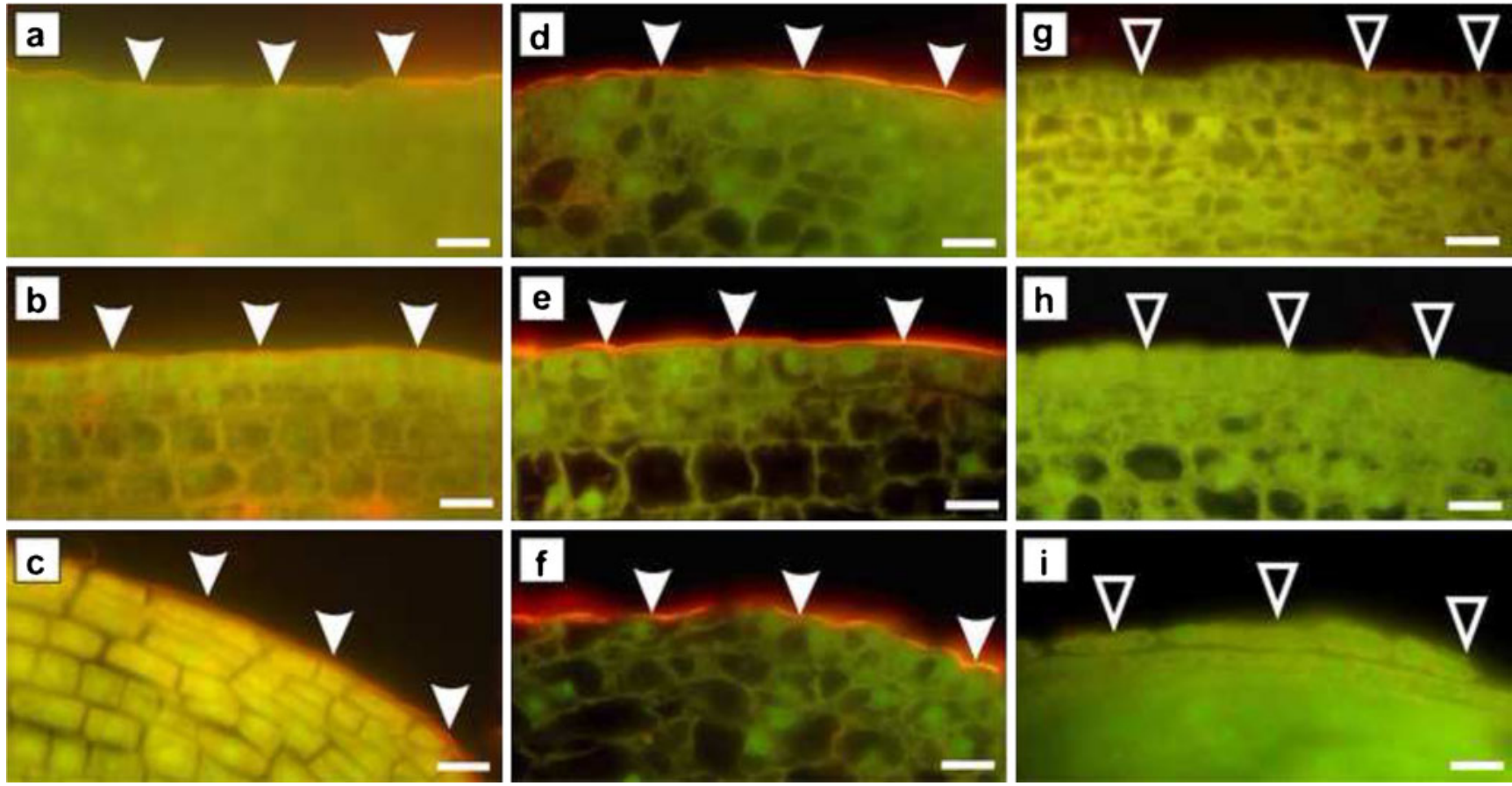

Fig. 1 Distribution of lipid substances - cuticle at the protodermal cell surface of Daucus carota embryos. Stained with Nile red; epifluorescence microscope, blue light. In zygotic embryos $(\mathbf{a}-\mathbf{c})$ and somatic embryos from solid culture $(\mathbf{d}-\mathbf{f})$ cuticular substances were present on the surface (indicated with filled arrowheads) of all protodermal cells independent of the embryo organ (a, $\mathbf{d}$-cotyledon, b, e-hypocotyl, c, f-root). In somatic embryos from suspension culture (g-i), lipid substances were not detectable on embryo surface (empty arrowheads; $\mathbf{g}$-cotyledon, $\mathbf{h}$-hypocotyl, $\mathbf{i}$-root). Scale bar $-2 \mu \mathrm{m}$ 
embryos at a mature stage of development, three layers of the outer periclinal walls were clearly visible: the pectocellulosic wall, the pectin lamellae and a cuticle (terminology after: Jeffree 1996). Part of the cell wall in the vicinity of the plasmalemma was almost electron translucent (Fig. 2a). Pectin lamellae were present in the outer periclinal walls and were continuous with the middle lamella of anticlinal walls (Fig. 2a). The cuticle was shown to be electron opaque, and under high magnification, it was observed that its structure was lamellar with an electron luscent wax lamellae (data not shown). Such a description is characteristic for protodermal cells from each embryo organ. At the surface of the cuticle osmophilic material was present; most probably a remnant of endosperm tissue (Fig. 2a).

\section{Somatic embryos}

In somatic embryos cultured on solid medium, the outer periclinal walls were different in comparison to zygotic embryo cell walls. The cuticle was in the form of an electron dense layer thicker in comparison to zygotic embryos (Fig. 2b). In the cuticle, the electron luscent layers (probably wax) were visible. The remainder of the wall was observed to be electron dense (Fig. 2b).
The outer periclinal, protodermal cell walls of embryos growing in suspension culture were completely devoid of cuticle, independent of the embryo organ (Fig. 2c). At the surface of these walls, only fibrillar material was present (Fig. 2c). This fibrillar material is most likely a pectin network as it was observed to be continuous with the pectin lamellae and with the middle lamellae in the anticlinal walls (data not shown). No differences in cell wall ultrastructure of protodermis between organs from each type of analysed embryos were observed.

Distribution of pectic epitopes recognised by JIM5 and JIM7

\section{Zygotic embryos}

The fluorescence signal generated by JIM5 within the zygotic embryo was not very intense and was not uniformly distributed in cell walls of the embryo. Microscopic analysis of sections from each organ revealed that the partially esterified pectic epitopes (recognised by JIM5) were present in all parenchyma cells of embryo organs and their distribution was uniform and punctate (Fig. $3 \mathrm{a}-\mathrm{c}$ ). In protodermal cells of cotyledons, in anticlinal cell walls and outer periclinal cell walls, the partially esterified pectic
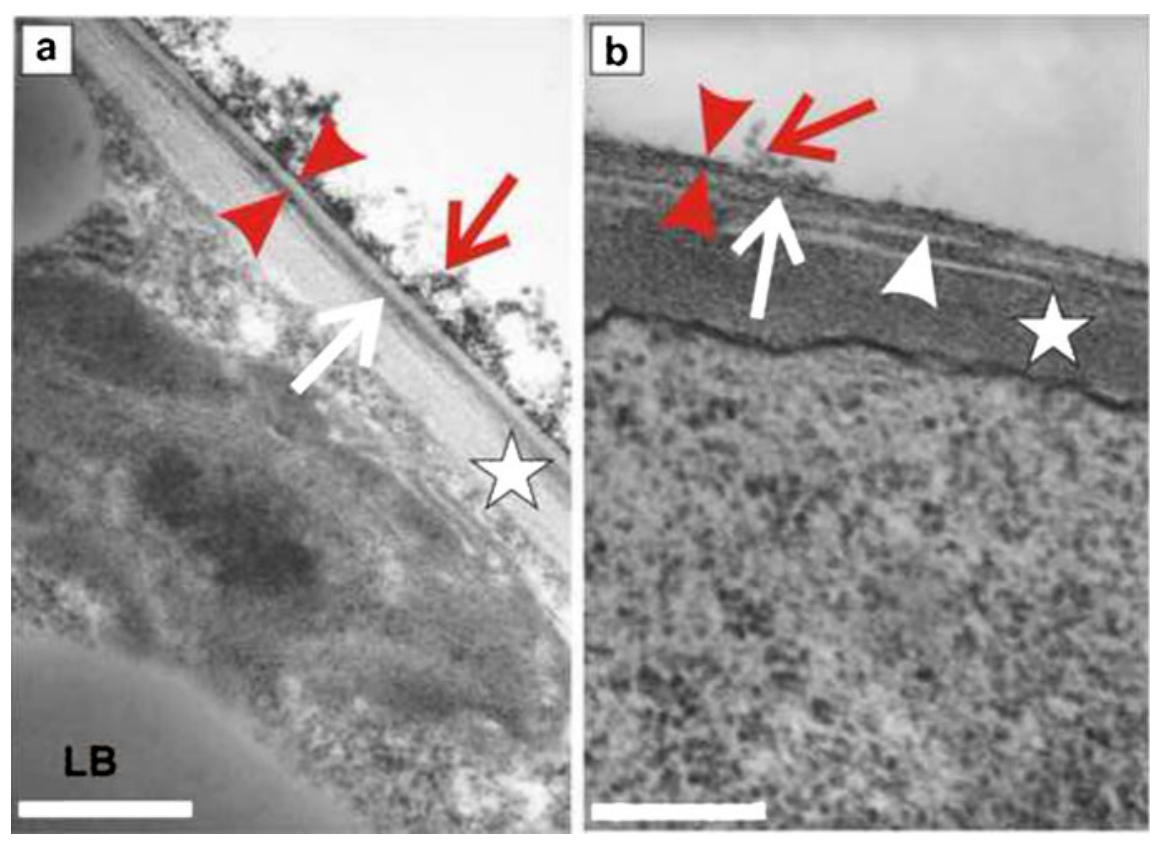

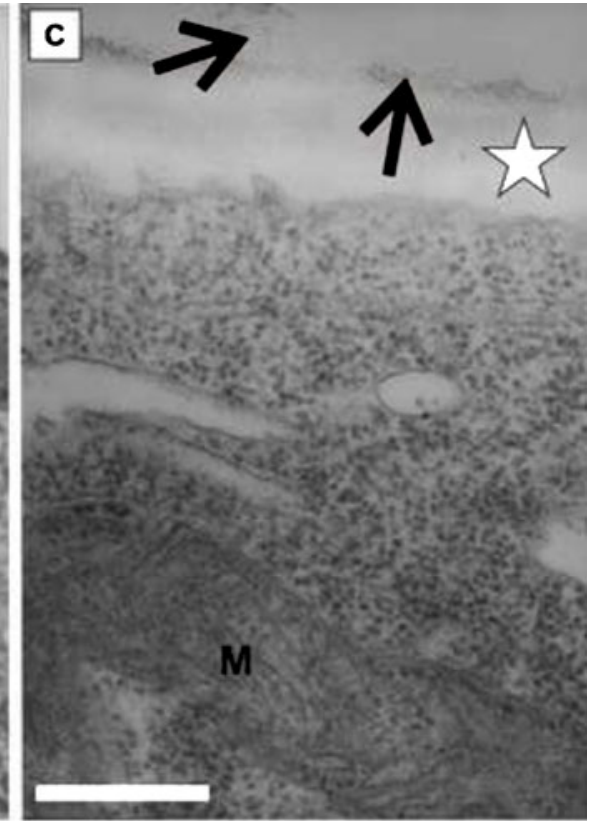

Fig. 2 TEM micrographs showing cell wall and cuticle ultrastructure of Daucus carota embryos. All pictures show protodermis from hypocotyl. In zygotic embryos (a) three layers of the outer periclinal walls was clearly visible: the pecto-celulosic wall (white asterix), the pectin lamelle (white arrow) and a cuticle (indicated with two red arrowheads to mark the cuticle thickness). In somatic embryos from solid medium (b) the cuticle forms of electron dense layer (red arrowheads); electron luscent layers (white arrowhead) visible in cuticle are composed probably by wax. On both embryo surface, zygotic (a) and somatic from solid culture (b), amorphous material with osmophilic granules is indicted by a red arrow. The outer periclinal walls of the protodermal cells from embryos growing in suspension culture (c) are completely devoid of cuticle; at the surface of this walls, only fibrillar material was present (black arrow). $L B$ lipid body, $M$ mitochondrium. Scale bar $-0.5 \mu \mathrm{m}$ 

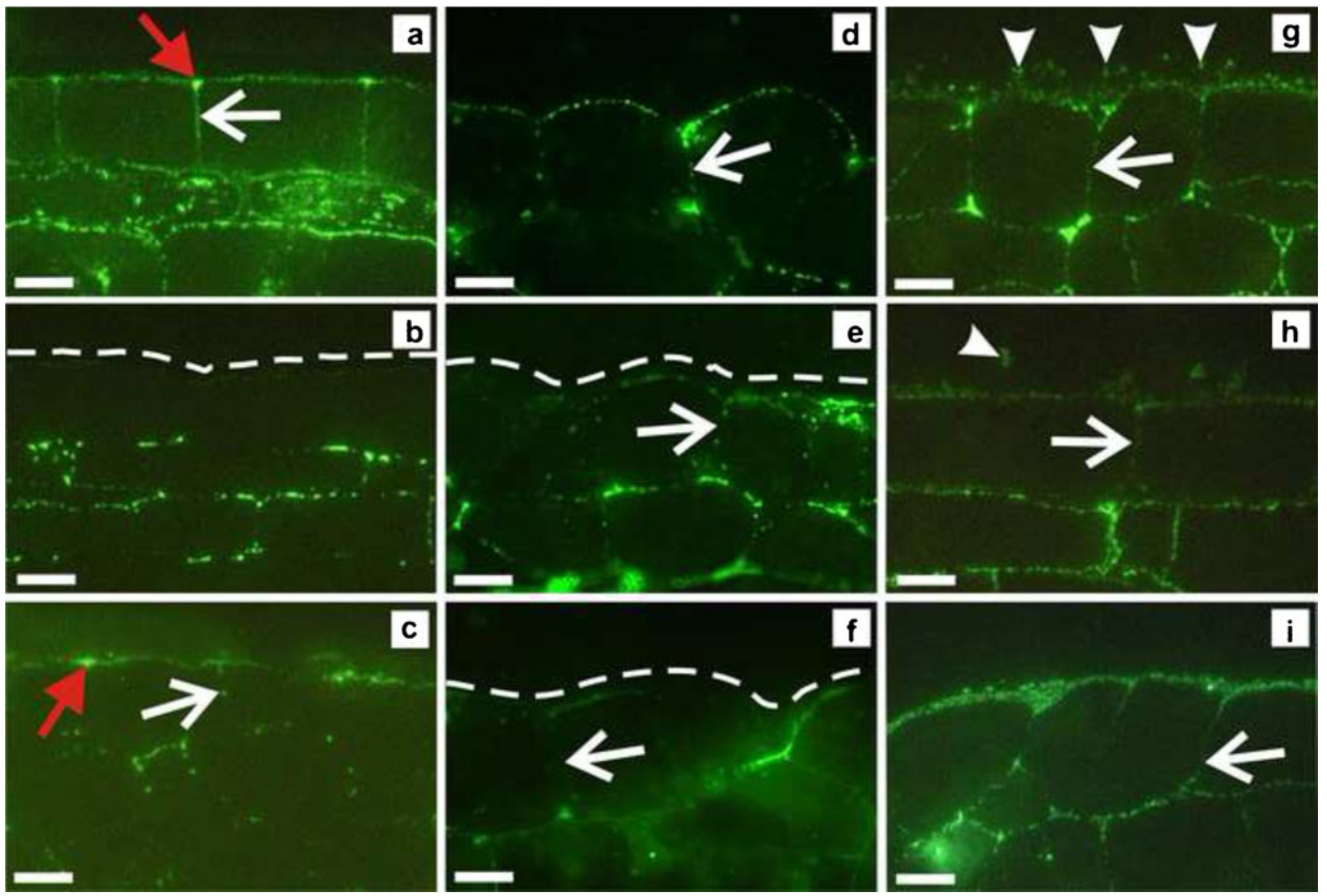

Fig. 3 Immunolocalization of pectin epitopes recognised by JIM5 antibodies in surface cells from Daucus carota embryos. The signal generated by JIM5 antibody within the protodermis cells of zygotic embryos (a-c) was not very intensive (the most intensive in pegs-red arrow) and punctate, not present in anticlinal walls of protodermis from hypocotyls (b) and low or very low in anticlinal walls (white arrow) in cotyledons (a) and roots (c), as well as in outer periclinal walls (white dashed line indicates the surface of the embryo as seen in the bright field). In somatic embryos from solid medium (d-f) signal from JIM5 antibody in protodermal cells was also very low and uniform (cotyledon — $\mathbf{d}$ and root $-\mathbf{f}$ ) or not present (hypocotyl $-\mathbf{e})$. In somatic embryos from suspension culture $(\mathbf{g}-\mathbf{i})$, punctate signal generated by JIM5 antibody was detected in all embryo organs (cotyledon- $\mathbf{g}$, hypocotyl $-\mathbf{h}$ and root $-\mathbf{i})$ with the higher concentration in that part of walls which was close to the cell protoplast; in roots the signal was distributed in the form of two layers in outer periclinal walls of protodermal cells; additionally, outside the outer periclinal walls of cotyledon and hypocotyls punctate signal from JIM5 was present (white arrowhead). Scale bar $-0.5 \mu \mathrm{m}$ epitopes were present and their distribution along the cell walls was punctate. Moreover, signal generated by JIM5 was particularly intensive in the corners between cells (pegs) in the outer periclinal walls (Fig. 3a). In the hypocotyl, partially esterified pectic epitopes were not present in the anticlinal walls of the protodermis. In the outer periclinal walls, the signal generated by JIM5 was so low, almost not to be visible (Fig. 3b). In the root protodermal cells, distribution of the partially esterified pectic epitopes was similar to the distribution in cotyledons (Fig. 3c).

The results described above suggest that partially esterified pectic epitopes in protodermal cells of zygotic embryos are present, but in very low concentrations. What is the most interesting is that they are almost absent in the outer periclinal walls which lies on the border between the embryo and the environment.

Distribution of pectic epitopes as recognised by JIM7 antibody were also analysed, and the signal generated by this antibody was shown to be more intense in comparison to the signal generated by JIM5. Analysis of the distribution of high-esterified pectic epitopes (recognised by JIM7) showed that this epitope was present in all ground meristem cell walls and that the distribution of signal generated by JIM7 was both uniform and intense (Fig. 4a-c). The distribution of the highly esterified pectic epitopes in protodermal cell walls from all embryo organs was similar (cotyledon-Fig. 4a, hypocotyl-Fig. 4b, root-Fig. 4c). The lowest signal from JIM7 was detected in the protodermal cells in their anticlinal walls. In some of these 

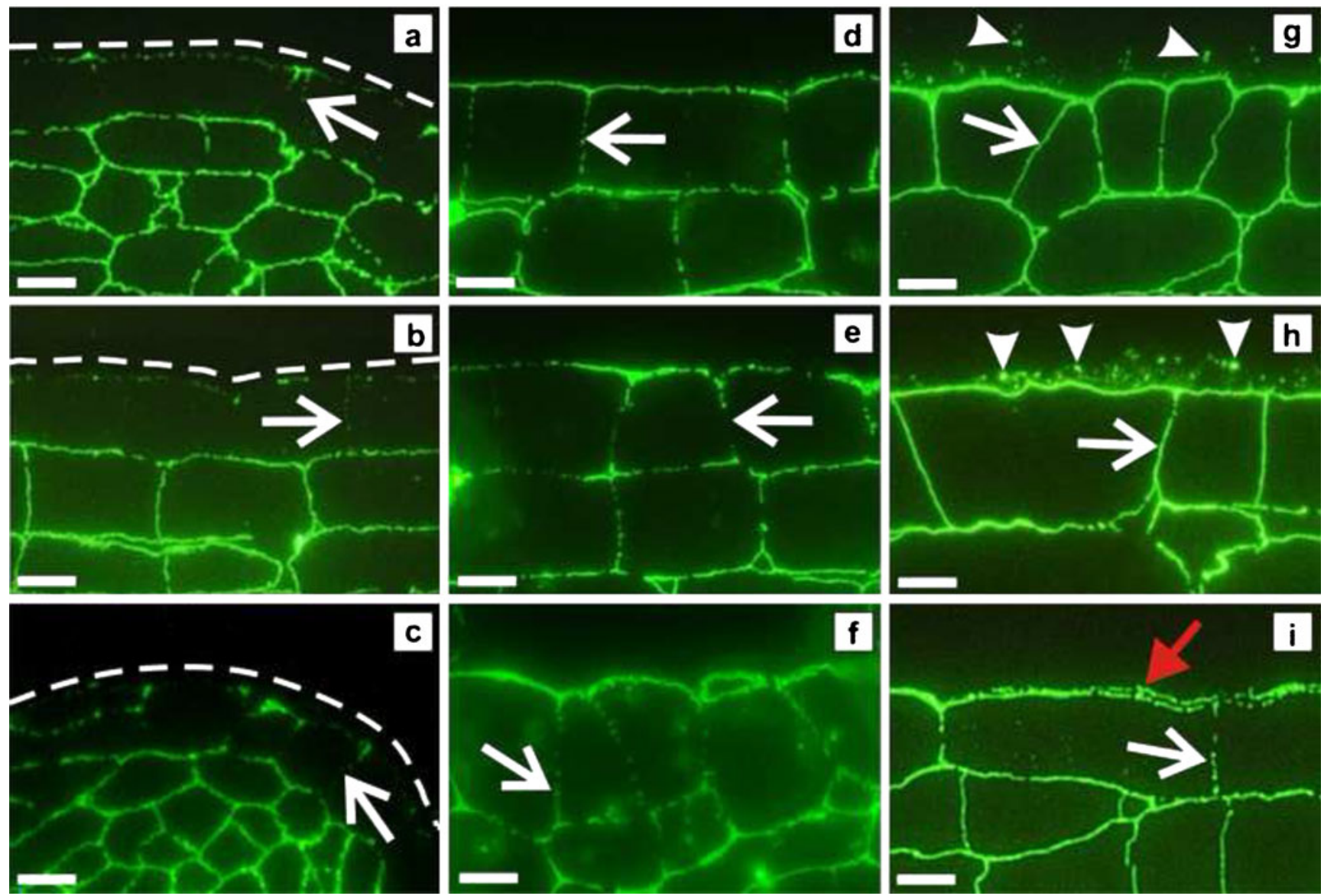

Fig. 4 Immunolocalization of pectin epitopes recognised JIM7 antibodies in surface cells from Daucus carota embryos. In zygotic embryos (a-c in all organs (cotyledon - a, hypocotyl $-\mathbf{b}$, root $-\mathbf{c}$ ), the distribution of pectin epitopes recognised by JIM7 antibody in periclinal cell walls of protodermis was punctate and not very intensive (white dashed line indicates the surface of the embryo as seen in the bright field); in anticlinal cell walls (white arrow), the signal was the lowest or even not detected. In somatic embryos from solid culture (d-f), signal generated by JIM7 antibody was punctate within all protodermal cell walls of the embryo. In somatic embryos

walls, even no epitope was detected (Fig. 4a-c). In outer periclinal, protodermal cell walls distribution of the highly esterified pectic epitopes was also punctate and not very intense (Fig. 4a-c).

\section{Somatic embryos from solid medium}

In embryos from solid medium, signal from JIM5 was very low and the most intense in cell corners within parenchyma cells (Fig. 3d-f). In some protodermal cells, label was present in the outer periclinal walls and its distribution was uniform, not punctate (Fig. 3d-f). There was no signal in the anticlinal walls of protodermal cells from the hypocotyl (Fig. 3e) or the signal was very low (in cotyledon-Fig. 3d and in root-Fig. 3f). Distribution and intensity of partially from suspension culture $(\mathbf{g}-\mathbf{i})$, the distribution pectin epitopes recognised by JIM7 antibody was uniform within all protodermal cell walls (cotyledon - $\mathbf{d}, \mathbf{g}$, hypocotyl - $\mathbf{e}, \mathbf{h}$ ) apart from the protodermis of root $(\mathbf{f}, \mathbf{i})$ - in anticlinal walls of protodermal cells from root the distribution of JIM7 antigen was punctate and in outer periclinal wall signal from JIM7 antibody created two layers (red arrow); outside the walls from cotyledon and hypocotyl close to the organ surface, very strong punctate signal was present (white arrowhead). Scale bar$0.5 \mu \mathrm{m}$

esterified pectic epitopes described above was the same in all embryo organs.

Signal generated by JIM7 was uniform within all cell walls of the embryo. In protodermal cells, it was present in the outer and inner periclinal walls and in the anticlinal walls, but the distribution of signal in the anticlinal walls was punctate (cotyledon-Fig. 4d, hypocotyl-Fig. 4e, root-Fig. 4f).

\section{Somatic embryos from suspension culture}

A weak signal generated by JIM5 was detected in walls of all of the embryo ground meristem, and its distribution was punctate. In all embryo organs (cotyledons-Fig. 3g, hypocotyls-Fig. $3 \mathrm{~h}$ and roots-Fig. 3i), the distribution 
of signal from JIM5 in protodermal cell walls was punctate with highest concentrations of label observed in that part of walls which was close to the cell protoplast. Moreover, in roots this pectic epitope was distributed in the form of two layers in outer periclinal walls of protodermal cells (Fig. 3i). The distribution of signal was punctuate, but uniform within the cell walls especially in the outer periclinal walls of protodermis. In addition, outside the outer periclinal walls of both cotyledons (Fig. $3 \mathrm{~g}$ ) and the hypocotyl (Fig. 3h), close to the organ surface, punctate signal from JIM5 was observed.

The distribution of signal generated by JIM7 within the walls of somatic embryos was more intense in comparison to signal generated by JIM5. The appearance of highly esterified pectic epitopes was uniform within all cell walls (cotyledon-Fig. 4g, hypocotyl-Fig. 4h) apart from the protodermis of the root (Fig. 4i). In anticlinal walls of protodermal cells of the root, the distribution of JIM7 epitope was punctate (Fig. 4i). In root (Fig. 4i), outer periclinal wall signal from JIM7 created two layers - one in the vicinity of the protoplast and the second-on the surface. Moreover, outside the walls of both cotyledons (Fig. 4g) and the hypocotyl (Fig. 4h), close to the organ surface, very strong signal in a punctate form was observed to be present.

\section{Discussion}

The presented data provide novel information on immunocytochemical and ultrastructural features of the outer periclinal walls and cuticle of protodermal cells of zygotic and somatic embryos of carrot.

Positive staining of the embryo surface with Nile red indicates that hydrophobic substances are located at the protodermis, and this is interpreted as being caused by the presence of a cuticle (Briggs and Morris 2008; Huang et al. 2009). Our results demonstrate that mature zygotic and somatic embryos from solid culture are enveloped by such substances. These data together with the TEM observation suggest the presence of a cuticle on the embryo surface of both zygotic and somatic embryos from solid culture. In mature zygotic embryos of Cimbidium sinense and $D$. carota, the presence of a cuticle has also been detected (Lackie and Yeung 1996; Yeung et al. 1996). Cuticle was also described in somatic embryos from solid culture in Coffea arabica (Nakamura et al. 1994), Feijoa sellowiana (Canhoto et al. 1996) or Oryza sativa (Mariani et al. 1999).

The structure of the cuticle is functionally significant for the exchange of water, solutes, gases and the deposition of different substances (Kerstiens 1996). It also protects the plant against UV radiation, mechanical damage, pathogens and insects (Reina-Pinto and Yephremov 2009). Moreover, the cuticle is involved in the generation and distribution of signals in plant-pathogen reactions (Kerstiens 1996; Schweizer et al. 1996). In addition, it provides mechanical strength and contributes to the viscoelastic properties of the cell wall (Hoffmann-Benning and Kende 1994). The detection of cuticle in the zygotic and somatic embryos from solid culture indicates that the developmental processes taking place during these two kinds of embryogenesis are similar and suggests that somatic embryogenesis on solid culture media is a good system for the analysis of developmental processes during zygotic embryogenesis.

Surprisingly, no staining with Nile red was detected on the surface of the mature somatic embryos from suspension cultures indicating the lack of such substances on the outer of protodermal cell walls. Analysis at the ultrastructure level also did not reveal the presence of cuticle in this type of embryo. A similar result was described previously for mature zygotic embryos of Arabidopsis, Capsella and Stellaria (Rodkiewicz et al. 1994). Also in studies with somatic embryos of Cichorium obtained from suspension culture lipid substances were not detected (Chapman et al. 2000). Instead, on the surface of embryos, fibrous material was present. Immunological analysis revealed that fibrillar material on the embryo surface was composed of pectins (Chapman et al. 2000).

The lack of the cuticle on the zygotic embryos surface is postulated as being an adaptation for absorption of nutrients from the endosperm when the suspensor is degenerated (Rodkiewicz et al. 1994). In somatic embryos from suspension culture the interpretation could be the same. Namely, embryos developed in the liquid environment must be adapted to absorb all the necessary substances directly from the culture. The lack of cuticle on the surface of the somatic embryos from suspension culture can be interpreted as a result of the development in "water" environment, but it is not the only possible way for adaptation to liquid environment. Ultrastructural studies of amphibious plants revealed the presence of cuticle also on the surface of submerged leaves. It was shown that permeability of oxygen was always lower in aerial cuticular membranes than in aquatic ones, from the same species (FrostChristensen et al. 2003). It means that cuticle does not make impossible transport of water, substances dissolved in water or gases. However, this result allows the presumption that an aquatic cuticle from amphibious plants differs in structure or composition from cuticle of terrestrial plants. Cuticle from submerged parts of amphibious plant is evolutionarily adapted to living in water. Also studies on some groups of lower plants (mosses, lichens) showed that their surface is adapted to liquid environment. They are able to absorb effectively water and nutrients over the complete surface of cuticle (for review, see Koch et al. 2008). In those species, superhydrophilicity of surface is 
based on different morphological structures. For instance in Sphagnum plants water uptake and gas exchange occur via special pores, which are spread over the plant body (Koch et al. 2008). Taking all these data together, we postulate that in studies of terrestrial plants somatic embryogenesis in suspension culture systems, the influence of liquid environment conditions on embryos development should be taken into account. In case of terrestrial plants, water environment conditions are not equivalent to natural conditions of development and it was shown in our studies that they influence protoderm cells of somatic embryos development.

The question whether the lack of cuticle is also typical for the earlier stages of embryo development requires further investigation, as protoderm formation is an essential step in embryo differentiation (de Jong et al. 1992) and presence of cutin is known to prevent organ fusion (Lolle et al. 1998; Tanaka et al. 2002). Studies with transgenic Arabidopsis expressing cutinase are characterized by altered cuticle ultrastructure in which an intact cutin layer is required for normal epidermal differentiation and organ formation (Sieber et al. 2000). Studies with mutants lacking epidermal waxes or mutants with changed cuticle composition showed that cuticle plays a significant role in either preventing or permitting organ fusions (Lolle et al. 1998; Tanaka et al. 2002; Panikashvili et al. 2007). Mutants that have cuticular defects exhibit a wide variety of phenotypes that concern different aspects of development, such as differences in the form of epidermal pavement cells, variations in stomata or trichome formation (Yephremov et al. 1999; Schnurr et al. 2004; Tanaka et al. 2002). All these phenotypes could potentially be caused by alterations in the generation or distribution of signal molecules because the changed cuticle is more permeable (Nawrath 2006). Synthesis of cuticular components is interconnected with generation of lipid-based signals that act in different developmental processes or plant defense (Bird and Gray 2003; Xiao et al. 2004; Zheng et al. 2005). On the other hand, studies with transgenic Arabidopsis plants expressing a fungal cutinase showed that the effect of cuticle alterations on development may also be indirect (Sieber et al. 2000). Plants with cutinase expression have altered cuticle structure, their cuticle forms a discontinuous layer but synthesis of cutin and other cuticle compounds is not disrupted. It seems possible that altered structure of the cuticle does not support normal deposition of intracuticular waxes, which are the major transport-limiting barrier in cuticle (Riederer and Schreiber 2001; Schreiber 2005). In our studies and others with embryos obtained from suspension culture, no organ fusion was observed. It is not surprising as, the suspension cultures must be agitated to provide sufficient amount of oxygen to the solution. During agitation cells, the cell aggregates or embryos are moved all the time and embryos' organs are not closely appressed during the development, which is essential for their fusion.

The question is to what degree the altered protodermal outer walls structure observed in somatic embryos from suspension culture can influence other embryo tissues development. In somatic embryos of some cuticular mutants, epidermal cell types differentiate normally even in the fused regions. Also internal tissue identities are maintained (Sinha and Lynch 1998). This may suggest that signal for differentiation of normal epidermis or other tissues comes from the plant inside and is independent of inputs from the outside. It was also observed that carrot somatic embryos surgically transected at different positions along the longitudinal axis are able to restore the excised tissues by reconfiguration the fates of cells at the surgical site (Schiavone and Racusen 1991). This implies that in the organization of body pattern of embryo position-dependent information plays an important role. Also studies on pattern of epidermal cell types of Arabidopsis seedling roots and hypocotyls confirm the position-dependent character of patterning (Lin and Schiefelbein 2001). On the other hand, the cell position is established on the basis of the cell-cell communication. In suspension, the cultures' variety of signals is released to the solution and this is one of the most important ways of the cell-cell communication in this type of culture (Chung et al. 1992). These signal molecules play an important role in the development of somatic embryos as either inhibitors or inducers (van Engelen et al. 1991; Quiroz-Figueroa et al. 2006, Matthys-Rochon 2005). Their effective secretion and absorption as a result of the lack of physical barrier which is cuticle, seems to be crucial for proper somatic embryo development.

Pectins are very heterogeneous family of polysaccharides located in the primary cell wall (Willats et al. 2001). This constituent of the cell wall participates in the maintenance of mechanical properties, porosity, ionic status of the walls, cell signalling and development (McCartney et al. 2000; Willats et al. 2001; Bárány et al. 2010). It has been shown that different developmental processes are accompanied by changes in pectin distribution, both qualitatively and quantitatively (Kikuchi et al. 1995, Kikuchi et al. 1995; Konieczny et al. 2007; Bárány et al. 2010). In the current study, the most interesting differences in the presence and absence of partially esterified and highly methyl-esterified pectins were observed between somatic embryos from suspension culture and other two types of analysed embryos. Both pectic epitopes were present in the outer periclinal walls of these embryos in high quantities in the vicinity of plasmalemma, but were also distributed in a punctate form outside the cell walls. Such a distribution of pectic epitopes is in accordance with the ultrastructure of the outer periclinal walls of these embryos where fibrillar material was observed to be present at the surface. 
In the case of mature zygotic embryos of Capsicum annuum signal generated by JIM5 antibody was found in the outer area embryo cell walls including protodermis, but signal generated by JIM7 antibody was not present in these cells (Bárány et al. 2010). It was also shown that between these two types of embryogenesis (zygotic and androgenic) at the mature stage no differences in the distribution of pectin epitopes were found which is in agreement with our data.

It was shown that de-esterification of pectins by methyl esterases is involved in specific developmental processes (Dolan et al. 1997). Predomination of partially esterified pectins recognised by JIM5 antibody was observed on the surface of globular somatic embryos of Cichorium (Chapman et al. 2000) and on embryogenic Cocos nucifera callus cells (Verdeil et al. 2001). Studies on $C$. annum pollen showed that highly esterified pectins are characteristic for proliferating cells, whereas nonesterified pectins are abundant in the walls of differentiating cells (Bárány et al. 2010). Moreover, other studies with growing tubes of Solanum chacoense pollen showed that transformation of methyl-esterified pectins into the de-esterified epitopes causes the cell wall to stiffen and to lose the viscoelasticity (Parre and Geitmann 2005). Additionally, degree of methylation influences cell wall porosity that has an important role for cell wall function or nutrient and signalling molecules transport (Tibbits et al. 1998; Zsivanovits et al. 2004; Ovodov 2009).

Here we have presented the distribution of pectic epitopes in the outer surface of somatic embryos from suspension culture. Pectic polysaccharide may provide the polar pathway for water movement within the epidermal walls (Riederer 2006). It has also been proposed that inorganic and small organic ions and water can move across the cuticle along polysaccharide strands which may consist of the pectic that was recorded in the current study (Schreiber 2005; Riederer and Friedmann 2006). Such an interpretation would also explain the ultrastructure and pectin in the outer periclinal protodermal walls of embryos from suspension culture, where cuticle was not detected.

It is considered that cuticle on embryo surface not only protects embryo against water loss, but also prevents turgor-driven water uptake if embryo is developing in highly hydrated conditions (Sterk et al. 1991) It was observed that somatic embryos of carrot consist of more highly vacuolated cells and are on average much larger than their zygotic counterparts of the same developmental stage. Proposed interpretation of such results was not a fully functional cuticle of somatic embryos growing in suspension culture (Sterk et al. 1991). Our findings that on somatic embryos from suspension culture instead of low permeable cuticle, highly permeable pectins are present seem to be a good explanation for bigger size of somatic embryos versus zygotic ones. However, it was observed in current studies that somatic embryos solid culture are also bigger than zygotic ones (data not shown), although both types of embryos are covered with cuticle. This finding implies that the reason for differences in zygotic and somatic embryos size is different. Additionally, it suggests that pectins may also play a mechanical role to limit embryo volume and maintain its cohesion as it was suggested after analysis of the embryo surface in Cichorium (Chapman et al. 2000).

In summary, it can be concluded that the ultrastructure and pectin distribution observed in the outer protodermal cell walls of somatic embryos from solid culture are similar to its zygotic counterparts. Somatic embryos from suspension culture are different in the ultrastructure of the outer protodermal walls, lacking of the cuticle and different distribution of pectin substances.

Special features of the ultrastructure and chemical composition of outer periclinal walls of somatic embryos from suspension culture suggest that the environment of the culture influences the development of embryo surface cells. The question as to how these features influence the flow of different substances across the protodermal cells and how they influence the embryo development will require further study.

Acknowledgement We thank Prof. Jerzy Klag and Dr Danuta Urbańska-Jasik from the Department of Animal Histology and Embryology (University of Silesia, Katowice) for providing TEM and technical help. We also thank Ewa Mazur from the Laboratory of Cell Biology (University of Silesia, Katowice) for sectioning of material for TEM.

Conflict of interest The authors declare that they have no conflict of interest.

Open Access This article is distributed under the terms of the Creative Commons Attribution Noncommercial License which permits any noncommercial use, distribution, and reproduction in any medium, provided the original author(s) and source are credited.

\section{References}

Atkinson RG, Schröder R, Hallett IC, Cohen D, MacRae EA (2002) Overexpression of polygalacturonase in transgenic apple trees leads to a range of novel phenotypes involving changes in cell adhesion. Plant Physiol 129:122-133

Baluška F, Parker JS, Barlow PW (1992) Specific patterns of cortical and endoplasmic microtubules associated with cell growth and tissue differentiation in roots of maize (Zea mays L.). J Cell Sci 103:191-200

Bárány I, Fadon B, Risueno MC, Testillano PS (2010) Cell wall components and estrification levels as markers of proliferation and differentiation events during pollen development and pollen embryogenesis in Capsicum annuum L. J Exp Bot 61:1159-1175

Baron-Epel O, Gharyal PK, Schindler M (1988) Pectins as mediators of wall porosity in soybean cells. Planta 175:389-395

Bird SM, Gray JE (2003) Signals from the cuticle affect epidermal cell differentiation. New Phytol 157:9-23 
Bobák M, Šamaj J, Hlinková E, Hlavačka A, Ovečka M (2003) Extracellular matrix in early stages of direct somatic Embryogenesis in leaves of Drosera spathulata. Biol Plant 47:161-166

Bouton S, Leboeuf E, Mouille G, Levdecker M-T, Talbotec J, Granier F, Lahaye M, Höfte H, Truong H-N (2002) QUASIMODO1 encodes a putative membrane-bound glycosyltransferase required for normal pectin synthesis and cell adhesion in Arabidopsis. Plant Cell 14:2577-2590

Bowman JL, Mansfield G (1993) Embryogenesis. In: Bowman JL (ed) Arabidopsis: An atlas of morphology and development. Springer-Verlag, New York, pp 351-398

Briggs CL, Morris EC (2008) Seed-coat dormancy in Grevillea linearifolia: little change in permeability to an apoplastic tracer after treatment with smoke and heat. Ann Bot 101:623-632

Brummell DA (2006) Cell wall disassembly in ripening fruit. Funct Plant Biol 33:103-119

Canhoto JM, Mesquita JF, Cruz G (1996) Ultrastructural changes in cotyledons of pineapple guava (Myrtaceae) during somatic embryogenesis. Ann Bot 78:513-521

Carpita NC, Gibeaut DM (1993) Structural models of primary cell walls in flowering plants: consistency of molecular structure with the physical properties of the walls during growth. Plant J 3:1-30

Chamberlin MA, Horner HT, Palmer RG (1993) Nutrition of ovule, embryo sac, and young embryo in soybean: an anatomical and autoradiographic study. Can J Bot 71:1153-1168

Chapman A, Blervacq AS, Hendriks T, Slomianny C, Vasseur J, Hilbert JL (2000) Cell wall differentiation during early somatic embryogenesis in plants II. Ultrastructural study and pectin immunolocalization on chicory embryos. Can J Bot 78:824-831

Chen W, Baldwin TC (2007) An improved method for the fixation, embedding and immunofluorescence labeling of resin-embedded plant tissue. Plant Mol Biol Report 25:27-35

Chung W, Pedersen H, Chin C-K (1992) Enhanced somatic embryo production by conditioned media in cell suspension cultures of Daucus carota. Biotechnol Lett 14:837-840

de Jong AJ, Cordewener J, LoSchiavo F, Terzi M, Vandekerckhove J, van Kammen D, de Vries SC (1992) A carrot somatic embryo in rescued by chitinase. Plant Cell 4:425-433

Derbyshire P, McCann MC, Roberts K (2007) Restricted cell elongation in Arabidopsis hypocotyls is associated with reduced average pectin esterification level. BMC Plant Biol 7:31-43

Dolan L, Linstead PJ, Roberts K (1997) Developmental regulation of pectic polysaccharides in the root meristem of Arabidopsis. J Exp Bot 48:713720

Dumville JC, Fry SC (2000) Uronic acid-containing oligosaccharins: their biosynthesis, degradation and signalling roles in nondiseased plant tissues. Plant Physiol Biochem 38:125-140

Fowler SD, Greenspan P (1985) Application of Nile red, a fluorescent hydrophobic probe, for the detection of neutral lipid deposits in tissue sections: comparison with Oil Red O. J Histochem Cytochem 33:833-836

Frost-Christensen H, Bolt Jørgensen L, Floto F (2003) Species specificity of resistance to oxygen diffusion in thin cuticular membranes from amphibious plants. Plant Cell Env 26:561-569

Gamborg OL, Miller RA, Ojima K (1968) Nutrient requirement of suspension cultures of soybean root cells. Exp Cell Res 50:151158

Halperin W (1964) Alternative morphogenetic events in cell suspensions. Am J Bot 53:443-453

Hawes C, Satiat-Jeunemaitre B (2001) Plant cell biology. Oxford University Press

Hetherington PR, Fry SC (1993) Xyloglucan endotransglycosylase activity in carrot cell suspension during cell elongation and somatic embryogenesis. Plant Physiol 103:987-992

Hoffmann-Benning S, Kende H (1994) Cuticle biosynthesis in rapidly growing internodes of deepwater rice. Plant Physiol 104:719-723
Huang G-H, Chen G, Chen F (2009) Rapid screening method for lipid production in alga based on Nile red fluorescence. Biomass Bioenerg 33:1386-1392

Jeffree CE (1996) Structure and ontogeny of plant cuticles. In: Kersiens G (ed) Plant cuticles and integrated functional approach. Bios Scientific Publishers, Oxford, pp 33-82

Kerstiens G (1996) Signalling across the divide: a wider perspective of cuticular structure-function relationships. Trends Plant Sci 1:125129

Kerstiens G (2006) Water transport in plant cuticles: an update. J Exp Bot 57:2493-2499

Kikuchi A, Satoh S, Nakamura N, Fujii T (1995) Differences in pectic polysaccharides between carrot embryogenic and nonembryogenic calli. Plant Cell Rep 14:279-284

Knox JP, Linstead PJ, King J, Cooper C, Roberts K (1990) Pectin esterification is spatially regulated both within cell walls and between developing tissues of root apices. Planta 181:512-521

Koch K, Barthlott W (2009) Superhydrophobic and superhydrophilic plant surfaces: an inspiration for biomimetic materials. Philos Trans R Soc A 367:1487-1509

Koch K, Bhushan B, Barthlott W (2008) Diversity of structure, morphology and wetting of plant surfaces. Soft Matter 4:19431963

Konieczny R, Świerczyńska J, Czaplicki AZ, Bohdanowicz J (2007) Distribution of pectin and arabinogalactan protein epitopes during organogenesis from androgenic callus of wheat. Plant Cell Rep 26:355-363

Kosma DK, Bourdenx B, Bernard A, Parsons EP, Lü S, Joubès J, Jenks MA (2009) The impact of water deficiency on leaf cuticle lipids of Arabidopsis. Plant Physiol 151:1918-1929

Kreuger M, Hoist G-J (1993) Arabinogalactan proteins are essential in somatic embryogenesis of Daucus carota L. Planta 189:243-248

Lackie S, Yeung EC (1996) Zygotic embryo development in Daucus carota. Can J Bot 74:990-998

Lee Y-I, Yeung EC, Lee N, Chung M-C (2006) Embryo development in the lady's slipper orchid, Paphiopedilum delenatii, with emphasis on the ultrastructure of the suspensor. Ann Bot 98:1311-1319

Li YQ, Chen F, Linskens HF, Cresti M (1994) Distribution of unesterified and esterified pectins in cell walls of pollen tubes of flowering plants. Sex Plant Reprod 7:145-152

Lin Y, Schiefelbein J (2001) Embryonic control of epidermal cell patterning in the root and hypocotyls of Arabidopsis. Dev 128:3697-3705

Lolle SJ, Hsu W, Pruitt RE (1998) Genetic analysis of organ fusion in Arabidopsis thaliana. Genet 149:607-619

Louvet R, Rayon C, Domon J-M, Rusterucci C, Fournet F, Leaustic A, Crépeau M-J, Ralet M-C, Rihouey C, Bardor M, Lerouge P, Gillet F, Pelloux J (2011) Major changes in the cell wall during silique development in Arabidopsis thaliana. Phytochem 72:5967

Mariani TS, Miyake H, Takeoka Y (1999) Epidermal cell wall biogenesis with emphasis on cuticular layer formation during direct somatic embryogenesis in rice. Plant Prod Sci 2:206-212

Matthys-Rochon E (2005) Secreted molecules and their role in embryo formation in plants: a mini-review. Acta Biol Cracov Bot 47:23-29

McCann MC, Stacey NJ, Wilson R, Roberts K (1993) Orientation of macromolecules in the walls of elongating carrot cells. J Cell Sci 106:1347-1356

McCartney L, Ormerod AP, Gidley MJ, Knox JP (2000) Temporal and spatial regulation of pectic $(1 \rightarrow 4)-\beta$-D-galactan in cell walls of developing pea cotyledons: implications for mechanical properties. Plant J 22:105-113

Mizukami M, Takeda T, Satonaka H, Matsuoka H (2008) Improvement of propagation frequency with two-step direct 
somatic embryogenesis from carrot hypocotyls. Biochem Eng J 38:55-60

Motose H, Sugiyama M, Fukuda H (2004) A proteoglycan mediates inductive interaction during plant vascular development. Nature 429:873-878

Murashige T, Skoog F (1962) A revised medium for rapid growth and bioassays with tobacco tissue cultures. Physiol Plant $15: 473-497$

Nakamura T, Taniguchi T, Maeda E (1994) Cyto-histological studies on somatic embryos of coffee: ultrastructural aspects. Jpn J Crop Sci 63:144-157

Nawrath C (2006) Unraveling the complex network of cuticular structure and function. Curr Opin Plant Biol 9:281-287

Newcomb W (1973) The development of the embryo sac of sunflower Helianthus annuus after fertilization. Can J Bot 51:879-890

Ovodov YS (2009) Current views on pectin substances. Russ J Bioorgan Chem 35:269-284

Panikashvili D, Savaldi-Goldstein S, Mandel T, Yifhar T, Franke RB, Höfer R, Schreiber L, Chory J, Aharoni A (2007) The Arabidopsis DESPERADO/AtWC11 transporter is required for cutin and wax secretion. Plant Physiol 145:1345-1360

Parre E, Geitmann A (2005) Pectin and the role of the physical properties of the cell wall in pollen tube growth of Solanum chacoense. Planta 220:582-592

Pennell RI, Janniche L, Scofield GN, Booij H, de Vries SC, Roberts K (1992) Identification of a transitional cell state in the developmental pathway to carrot somatic embryogenesis. J Cell Biol 119:1371-1380

Quiroz-Figueroa FR, Rojas-Herrera R, Galaz-Avalos RM, LoyolaVargas VM (2006) Embryo production through somatic embryogenesis can be used to study cell differentiation in plants. Plant Cell Tiss Organ Cult 86:285-301

Raghavan V (1986) Embryogenesis in angiosperms. Cambridge University Press, Cambridge, UK

Reina-Pinto JJ, Yephremov A (2009) Surface lipids and plant defenses. Plant Physiol Biochem 47:540-549

Reynolds ES (1963) The use of lead citrate at high $\mathrm{pH}$ as an electronopaque stain in electron microscopy. J Cell Biol 17:208-212

Riederer M (2006) Introduction: biology of the plant cuticle. In: Riederer M, Müller C (eds) biology of the plant cuticle. Blackwell Publishing Ltd, Oxford, pp 1-10

Riederer M, Friedmann A (2006) Transport of lipophilic nonelectrolytes across the cuticle. In: Riederer M, Müller C (eds) Biology of the plant cuticle. Blackwell Publishing Ltd, Oxford. Pp, pp 250-279

Riederer M, Schreiber L (2001) Protecting against water loss: analysis of the barrier properties of plant cuticles. J Exp Bot 52:20232032

Rodkiewicz B, Fyk B, Szczuka E (1994) Chlorophyll and cutin in early embryogenesis in Capsella, Arabidopsis, and Stellaria investigated by fluorescence microscopy. Sex Plant Reprod 7:287-289

Satoh S (1998) Functions of the cell wall in the interactions of plant cells: analysis using carrot cultured cells. Plant Cell Physiol 39:361-368

Schiavone FM, Racusen RH (1991) Regeneration of the root pole in surgically transected carrot embryos occurs by positiondependent, proximodistal replacement of missing tissues. Dev 113:1305-1313

Schnurr J, Shockey J, Browse J (2004) The acyl-CoA synthetase encoded by $L A C S$ is essential for normal cuticle development in Arabidopsis. Plant Cell 16:629-642

Schreiber L (2005) Polar paths of diffusion across plant cuticles: new evidence for an old hypothesis. Ann Bot 95:1069-1073

Schweizer P, Jeanguenat D, Whitacre D, Métraux J-P, Mösinger E (1996) Induction of resistance in barley against Erysiphe graminis f.sp. hordei by free cutin monomers. Physiol Mol Plant Pathol 49:103-120

Shimazu T, Kurata K (1996) Relationship between production of carrot somatic embryos and dissolved oxygen concentration in liquid culture. Plant Cell Tissue Organ Cult 57:29-38

Sieber P, Schorderet M, Ryser U, Buchala A, Kolattukudy P, Métraux J-P, Nawrath C (2000) Transgenic Arabidopsis plants expressing fungal cutinase show alteration in the structure and properties of the cuticle and postgenital organ fusions. Plant Cell 12:721-737

Sinha N, Lynch M (1998) Fused organs in the adherent1 mutation in maize show altered epidermal walls with no perturbations in tissue identities. Planta 206:184-195

Steeves TA, Sussex IM (1989) Patterns in plant development. Cambridge University Press

Sterk P, Booij H, Schellekens GA, Kammen AV, de Vries SC (1991) Cell-specific expression of the carrot EP2 lipid transfer protein gene. Plant Cell 3:907-921

Steward FC, Mapes MO, Smith J (1958) Growth and organized development of cultured cells. I. Growth and division of freely suspended cells. Am J Bot 45:693-704

Szczuka E (1995) Patterns of cuticle localization in developing dicotyledonous embryos with reduced and extended suspensors. Bull Pol Acad Sci Biol Sci 43:191-194

Szczuka E, Szczuka A (2003) Cuticle fluorescence during embryogenesis of Arabidopsis thaliana (L.) Heynh. Acta Biol Crac Ser Bot 45:63-67

Tanaka H, Watanabe M, Watanabe D, Tanaka T, Machida C, Machida Y (2002) ACR4, a putative receptor kinase gene of Arabidopsis thaliana, that is expressed in the outer layers of embryos and plants, is involved in proper embryogenesis. Plant Cell Physiol 43:419-428

Tibbits CW, MacDougall AJ, Ring SG (1998) Calcium binding and swelling behaviour of a high methoxyl pectin gel. Carbohydr Res 310:101-107

Timbert R, Barbotin JN, Thomas D (1996) Enhancing carrot somatic embryos survival during slow dehydration, by encapsulation and control of dehydration. Plant Sci 120:215-222

Toonen MAJ, Schmidt EDL, van Kammen A, de Vries SC (1997) Promotive and inhibitory effects of diverse arabinogalactan proteins on Daucus carota L. somatic embryogenesis. Planta 203:188-195

van Engelen FA, Sterk P, Booij H, Cordewedner JHG, Rook W, van Kammen Ab, de Vries SC (1991) Heterogeneity and cell typespecific localization of a cell wall glycoprotein from carrot suspension cells. Plant Physiol 96:705-712

van Lammeren AAM (1986) Developmental morphology and cytology of the young maize embryo (Zea mays L.). Acta Bot Neerl 35:169-188

Verdeil JL, Hocher V, Huet C, Grosdemange F, Escoute J, Ferrière N, Nicole M (2001) Ultrastructural changes in coconut calli associated with the acquisition of embryogenic competence. Ann Bot 88:9-18

Wi SG, Singh AP, Lee KH, Kim YS (2005) The pattern of distribution of pectin, peroxidase and lignin in the middle lamella of secondary xylem fibres in alfalfa (Medicago sativa). Ann Bot 95:863-868

Willats WG, McCartney L, Mackie W, Knox JP (2001) Pectin: cell biology and prospects for functional analysis. Plant Mol Biol 47:9-27

Wisniewska E, Majewska-Sawka A (2007) Arabinogalactan-proteins stimulate the organogenesis of guard cell protoplasts-derived callus in sugar beet. Plant Cell Rep 26:1457-1467

Wurtele ES, Wang H, Durgerian S, Nikolau BJ, Ulrich TH (1993) Characterization of a gene that is expressed early in somatic embryogenesis of Daucus carota. Plant Physiol 102:303-312 
Xiao F, Goodwin SM, Xiao YM, Sun ZY, Baker D, Tang XY, Jenks MA, Zhou JM (2004) Arabidopsis CYP86A2 repressed Pseudomonas syringae type III genes and is required for cuticle development. EMBO J 23:2903-2913

Yephremov A, Wisman E, Huijser P, Huijser C, Wellesen K, Saedler H (1999) Characterization of the FIDDLEHEAD gene of Arabidopsis reveals a link between adhesion response and cell differentiation in the epidermis. Plant Cell 11:21872201
Yeung EC, Zee SY, Le XL (1996) Embryology of Cymbidium sinense: embryo development. Ann Bot 78:105-110

Zheng H, Rowland O, Kunst L (2005) Disruption of the Arabidopsis enoyl-CoA reductase gene reveal as essential role for very-longchain fatty acid synthesis in cell expansion during plant morphogenesis. Plant Cell 17:1467-1481

Zsivanovits G, MacDougall AJ, Smith AC, Ring SG (2004) Material properties of concentrated pectin networks. Carbohydr Res 339:1317-1322 